\title{
Data Acquisition Prototype Chamber of Mechanical Seals Test Plant API-682 Using NI MY-RIO ${ }^{\mathrm{TM}}$
}

\author{
Adhitya Sumardi \\ Politeknik Manufaktur Bandung \\ adhitya@polman-bandung.ac.id \\ Noval Lilansa \\ Politeknik Manufaktur Bandung \\ M. Nursyam \\ Politeknik Manufaktur Bandung
}

\author{
Afaf Fadhil Rifai \\ Politeknik Manufaktur Bandung \\ afaf_fadhil@yahoo.com \\ Fachri Iman \\ Politeknik Manufaktur Bandung \\ Yunita Indah Sari \\ Politeknik Manufaktur Bandung
}

\begin{abstract}
Seal Chamber in Mechanical Seal Test Plant is a part that is used for heat exchange between hot liquid fluid in the form of condensed steam and cold liquid fluid in mechanical seal test plant. In heat exchange it is arranged so that the hot fluid can raise and lower the temperature from $20{ }^{\circ} \mathrm{C}$ to $80{ }^{\circ} \mathrm{C}$ and vice versa within $1-2$ minutes. In the exchange of heat, data acquisition is still needed, which is then processed by data acquisition software that has been calibrated to determine the sensor response to the environment for test plant. In this study, data acquisition and monitoring systems were carried out and multi tasking synchronization with several sensors with one centralized controller. In addition, the volume seal chamber is equipped with a valve regulated by a servo motor to regulate the amount of hot liquid fluid in the form of condensed steam. Valve is used to be a regulator of the flow of hot fluid that enters and exits the seal chamber volume model. This research will be used to control the level and temperature in prototype of the Mechanical Sil test plant according to API 682. The manual control is done and there is an average error for the relationship of the actual valve with the water flow sensor of $8.42 \%$.
\end{abstract}

Keyword - Prototype of the Mechanical Sil Test Plant, API 682, sensor

\section{INTRODUCTION}

Today Mechanical seals used in all Indonesian industries are $99.9 \%$ imported from abroad. One of the manufacturing industries in Indonesia tries to contribute in supplying the mechanical needs in Indonesia. This contribution is also expected to be able to advance the development of Indonesian mechanical seals technology. Technological development cannot be done alone by the industry but requires support and good cooperation with educational institutions. In this case, Polman as one of the institutions in manufacturing welcome the collaboration carried out by Sil Mechanical manufacturers from Indonesia. One important factor determines the quality of mechanical seals, namely testing. Nowadays mechanical testing equipment is still dominated by imports so it needs to be developed domestically to complete the Sil Mechanical System. The standard used in this test device is the API standard (American Petrolium Institute) 682. The following is a picture of a mechanical seal test plant. 


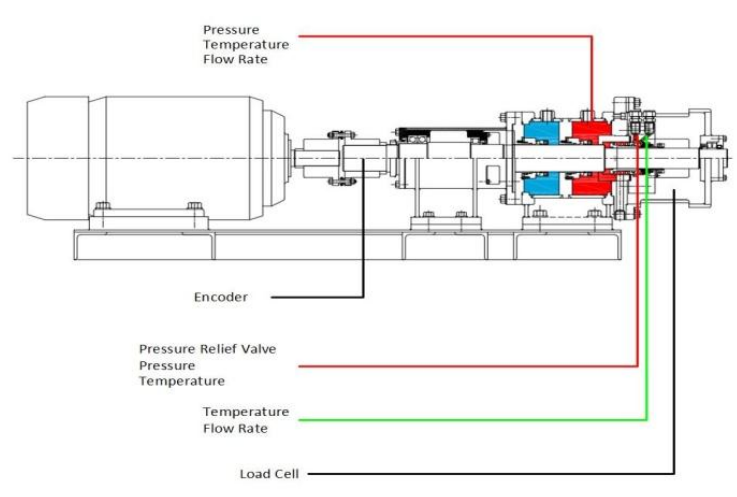

Figure 1. Design of the Mechanical Seal Test Plant

In the mechanical seal test plant there are three modes of testing, including dynamic, static and cyclic. The parameters that must be met include temperature, motor rotation and pressure.

The aim to be achieved in the research is to make laboratory scale mechanical seal test plant to fulfill temperature parameters in cyclic mode.

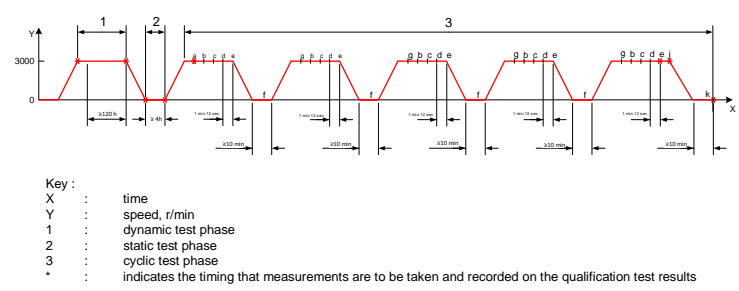

Figure 2. Cyclic Mode for API Test Plan 682

This research is expected to provide benefits for both teachers and students. The benefit for teaching staff is that it can provide convenience in teaching the material for temperature and water level control systems, so that the material is delivered more effectively and students are more actively involved in practicing the material presented, so that the learning process will occur in two directions. Other benefits students will more easily understand / accept material and be more communicative with the use of mini plans. In addition, it is expected that the results of this study can be applied to fulfill the paramareter on mechanical sil test equipment.

\section{RESEARCH METHODOLOGY}

The implementation of the research will be more clearly done by establishing a research basis, the research framework represents the focus of the research, shown in Figure 2

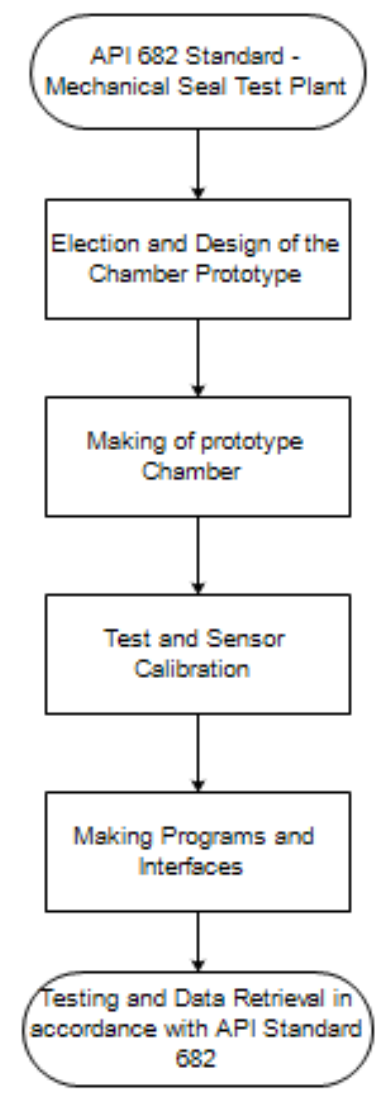

Figure 3. Research Framework

The making of a mechanical sil test equipment starts from making chamber controls on a mechanical scale laboratory test plant using several sensors. Following are the stages of research for making prototypes of test equipment, including:

a. The first stage is looking for literature and studying literature related to this theme. The use of the API 682 standard in the process of the mechanical seal test requires supporting data about the characteristics of the sensor. Literature studies including datasheet, brochure and textbook will be able to support the making of tools.

b. The second stage is the selection of the type of sensor to be used and the prototype for prototype mechanical seal test plant. In this case, there are two mechanical taps in the mechanical seal test apparatus in the form of hot water and cold 
water. In addition, there is a faucet for the discharge of the chamber water.

c. The third stage is the making of mechanics from prototype mechanical sil test plant, testing and sensor calibration. There are several sensors in the prototype of mechanical sil test equipment including waterflow sensors, thermocouple, and non-contact liquid switch sensors.

d. The fourth stage is the making of programs and interfaces for prototype of mechanical sil testtest. Then testing and retrieving data regarding the relationship between the actual valve and the water valve sensor.

\section{RESULT AND IMPLEMENTATION}

Parameters observed and controlled are temperature and water level. The sensor is used to detect temperature at both input and output, the waterflow sensor will detect water discharge and for the water level in the chamber using a non-contact liquid switch sensor. Data generated from the entire sensor consists of analog data and digital data. The data is then entered into the NI-myRio controller and displayed on a computer screen in real time using the LabView programming system. The following is a prototype system for mechanical sil test pant.

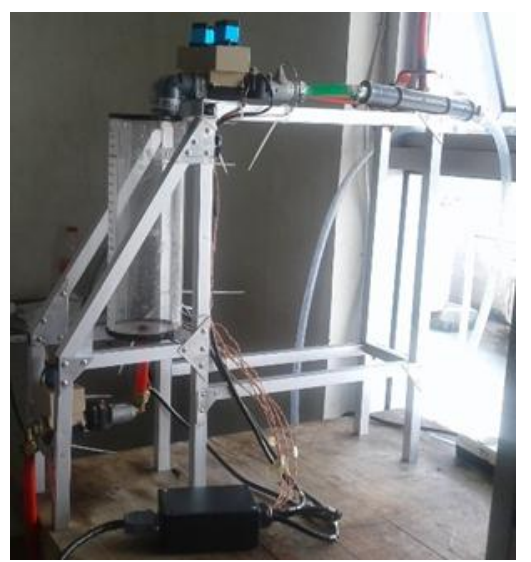

Figure 4. Prototype of the Mechanical Sil Test Plant

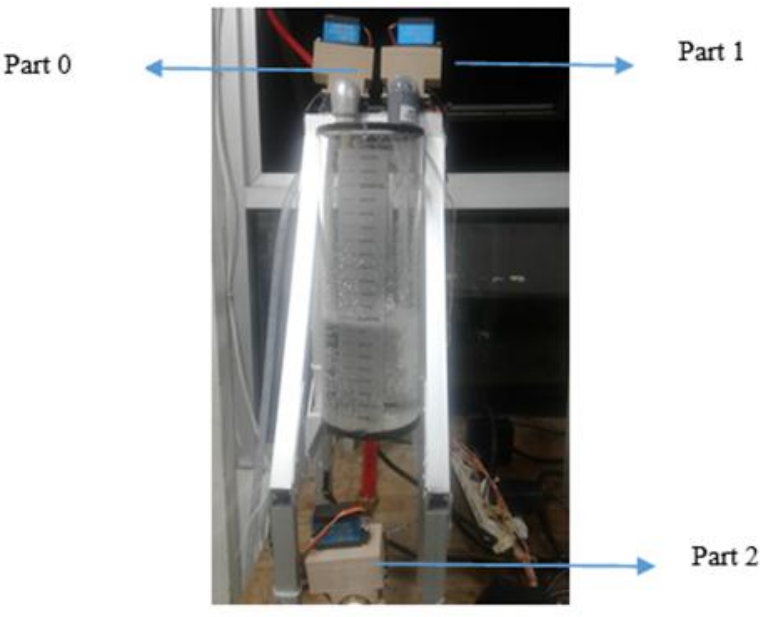

Figure 5. Sections of Mechanical Sil Test System Prototype

Based on the picture above, there are 3 parts of the prototype system for mechanical seal test, for part 0 for hot water, part 1 for cold water and part 3 for water that comes out of the chamber. The following figure is a sensor placement a Prototype of the Mechanical Sil Test Plant

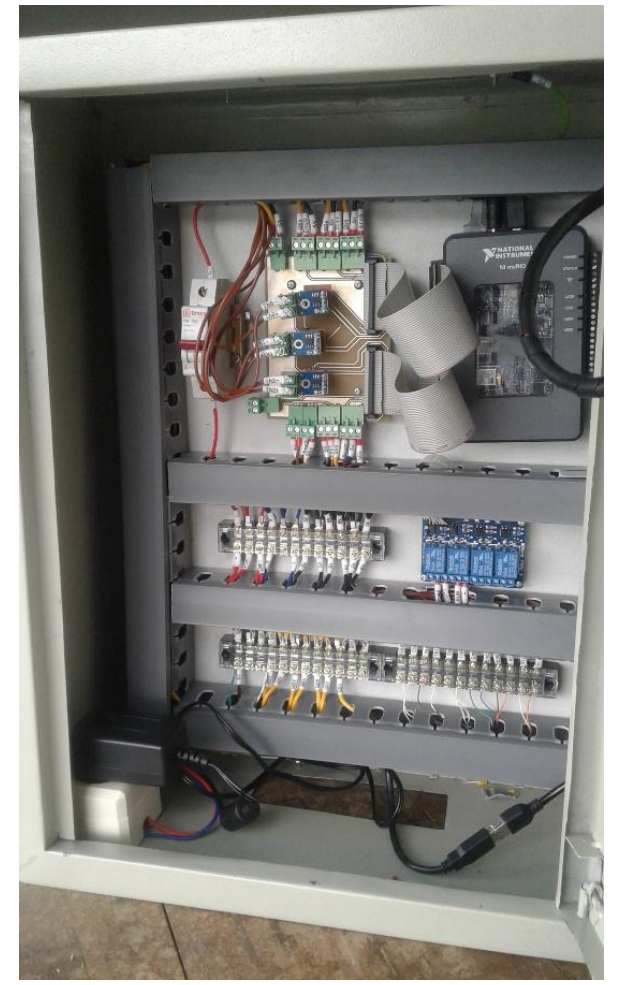

Figure 6. Control Panel for Prototype of the Mechanical Seal Test System using NI MyRio 


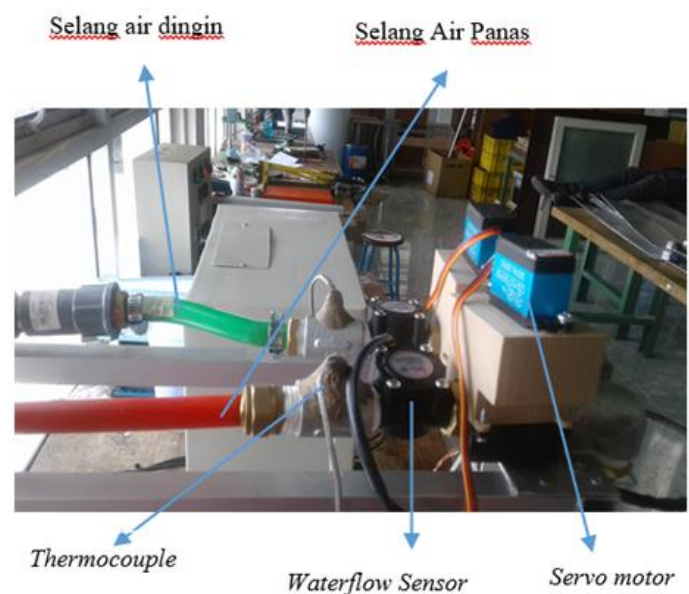

Figure 7. Prototype of the Mechanical Seal Test System

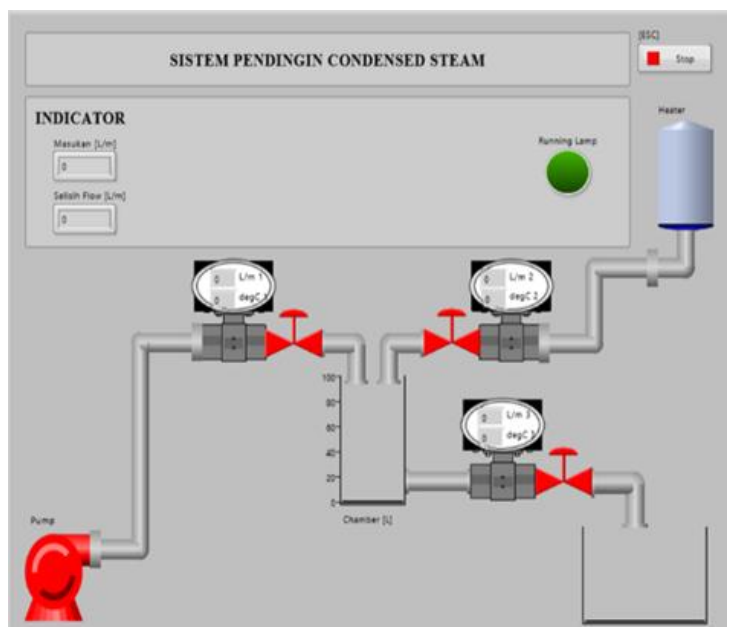

Figure 8. Interface of temperature and water flow readings

The interface to the prototype system is the mechanical sil test plant using Labview and myRio from National Instrument. In the picture above the interface displays readings of water flow, temperature at the plant, indicator lights when the plant is running, and the amount of water flow in and out.

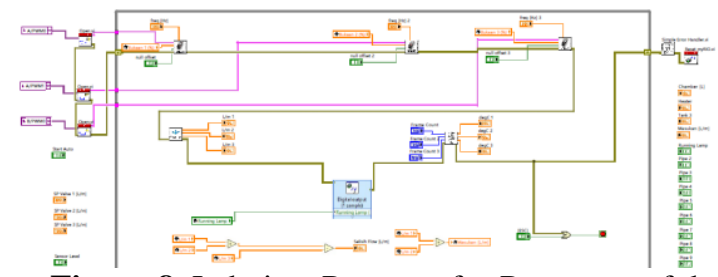

Figure 8. Labview Program for Prototype of the Mechanical Seal Test Plant

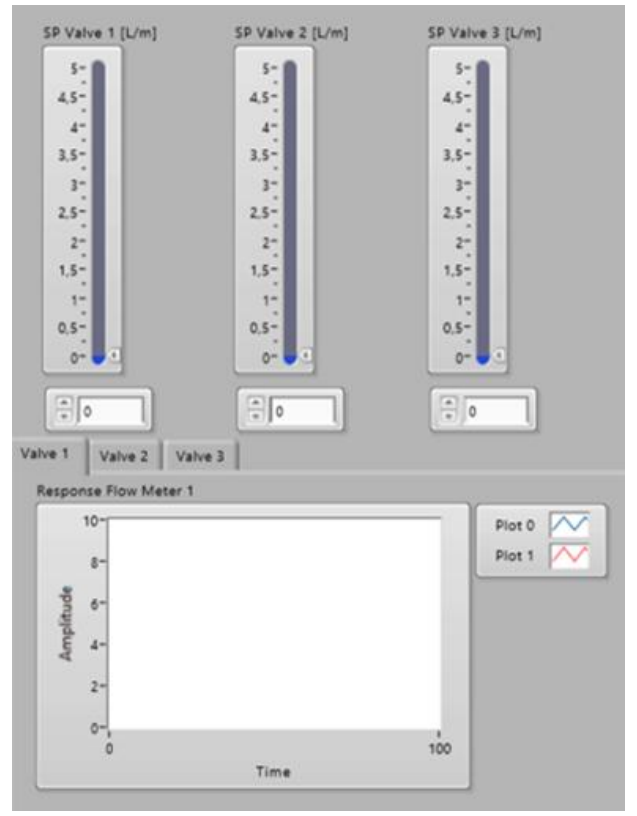

Figure 9. Prototype of the Mechanical Seal Test Plant

The type of valve used in this research is a ball valve. This ball valve is driven by using a servo motor. The servo motor movement will be translated to regulate the opening in the ball valve. Water discharge through the valve is detected using a waterflow sensor. The following is a graph of the relationship between the actual opening of the valve and the waterflow sensor.

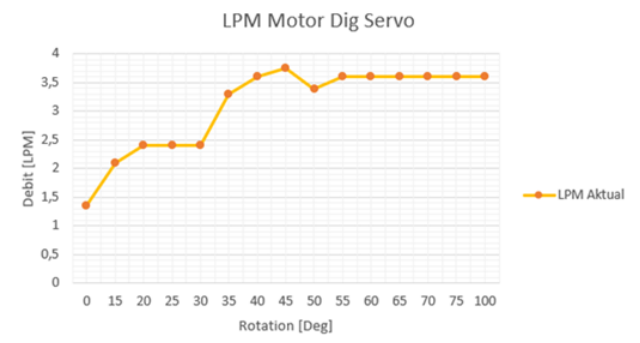

Figure 10. Graph of Actual Relationship Valve Wate Flow Sensor 
Based on the graph above it appears that the graph produced between valve openings and water discharge is not linear. The valve is regulated by the percentage of movement of the ball on the tap. The following is a comparison chart between the graph of the actual valve and the reading on the sensor

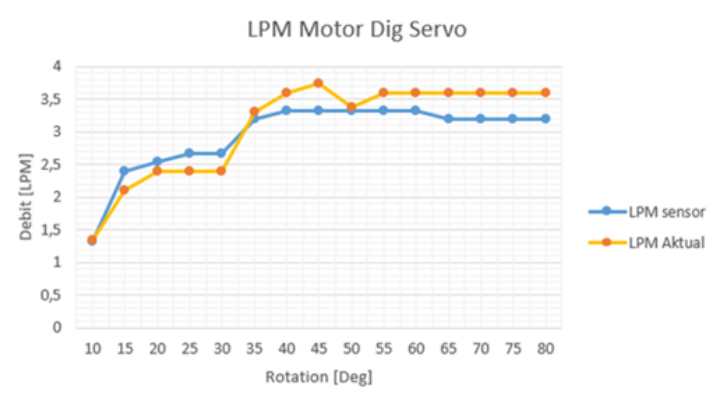

Figure 11. Actual Valve Comparison - Water Flow Sensor

The graph of the comparison between the readings of the waterflow sensor and the actual valve produced an average error of $8.42 \%$. An error occurred because of an imperfect valve opening and sensor readings that still contained noise. Below is a complete data table of error values from comparing readings of waterflow sensors and actual valves.

Table 1. Error of Actual Valve - Water Flow Sensor

\begin{tabular}{ccccc}
\hline Valve (\%) & $\begin{array}{c}\text { Debit } \\
\text { Sensor } \\
(\mathbf{L} / \mathrm{m})\end{array}$ & $\begin{array}{c}\text { Volum Act } \\
(\mathrm{ml})\end{array}$ & $\begin{array}{c}\text { Act } \\
(\mathbf{L} / \mathrm{m})\end{array}$ & $\begin{array}{c}\text { Error Water } \\
\text { Flow Meter (\%) }\end{array}$ \\
\hline 10 & 1,33 & 1200 & 1,35 & 1,48 \\
\hline 15 & 2,4 & 1200 & 2,1 & 14,29 \\
\hline 20 & 2,533 & 1200 & 2,4 & 5,54 \\
\hline 25 & 2,67 & 1200 & 2,4 & 11,25 \\
\hline 30 & 2,67 & 1200 & 2,4 & 11,25 \\
\hline 35 & 3,2 & 1200 & 3,3 & 3,03 \\
\hline 40 & 3,33 & 1125 & 3,6 & 7,50 \\
\hline 45 & 3,33 & 1250 & 3,75 & 11,20 \\
\hline 50 & 3,33 & 1200 & 3,375 & 1,33 \\
\hline 55 & 3,33 & 1100 & 3,6 & 7,50 \\
\hline 60 & 3,33 & 800 & 3,6 & 7,50 \\
\hline 65 & 3,2 & 800 & 3,6 & 11,11 \\
\hline 70 & 3,2 & 800 & 3,6 & 11,11 \\
\hline 75 & 3,2 & 700 & 3,6 & 11,11 \\
\hline 80 & 3,2 & 450 & 3,6 & 11,11 \\
\hline \multicolumn{5}{c}{ Average } \\
\hline \multicolumn{7}{c}{}
\end{tabular}

The following are the graph results for the fulfillment of the temperature rate. There are two conditions for temperature changes, namely when 80 ${ }^{\circ} \mathrm{C}$ becomes $20{ }^{\circ} \mathrm{C}$ and vice versa.

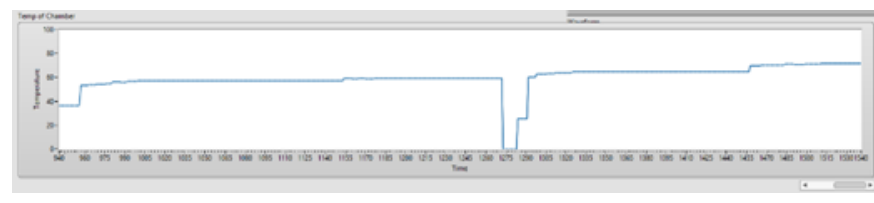

Figure 12. Changes in temperature rise

In the picture above it is the stage of temperature change from $20{ }^{\circ} \mathrm{C}$ to $80{ }^{\circ} \mathrm{C}$. The result of actualization takes 60 seconds to change the temperature of $37{ }^{\circ} \mathrm{C}$ to $75{ }^{\circ} \mathrm{C}$ because the valve on the cold tap cannot close completely, cooling occurs when hot water flows towards the taps and the limited water in the tank. So it's difficult to reach a value of $80{ }^{\circ} \mathrm{C}$.

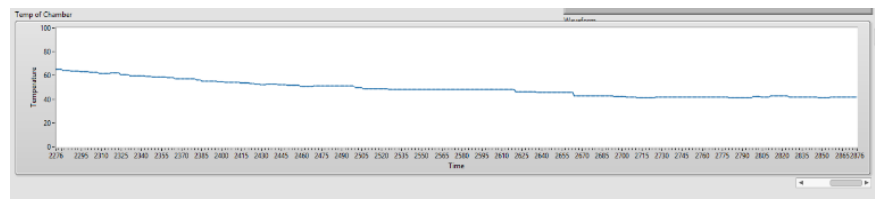

Figure 13. Changes in temperature decrease

The result of the graph above is a temperature change from $80{ }^{\circ} \mathrm{C}$ to $20{ }^{\circ} \mathrm{C}$. It is the same as the graph which before the required time is around 60 seconds and the temperature change that can be done is at $75{ }^{\circ} \mathrm{C}$ to $37{ }^{\circ} \mathrm{C}$ because the valve part of the heat cannot close so there is still a leak.

\section{CONCLUSION}

The API 628 standard is used in mechanical seal test plant. In prototypes, mechanical seal test plant is carried out to control the fulfillment of temperature parameters. The microcontroller device used on the system is NI-myRio with the Labview interface. While the sensors contained in the plant include waterflow sensors, thermocouple, and non-contact liquid switch sensors. Valve for water openings is driven by a percentage by a servo motor. Manually controlling is done and the average error results for the relationship of the actual valve with the water flow sensor is $8.42 \%$. 


\section{REFERENCES}

[1] Kurniawan, \& Yudianto, O. (2014). Kajian Kegagalan Kinerja Sil Mekanik Produksi Dalam Negeri. Seminar Nasional - XIII Rekayasa dan Aplikasi Teknik Mesin di Industri ITENAS , 25.

[2] Eagle Burgmann. (t.t). API 6824 th edition piping plan. German : EagleBurgmann Germany GmbH \& Co. KG.

[3] National Instrumets. (t,t). MyRio-1900 student embedded.[Online]. Available in : http://www.ni.com/en-id/support/model.myrio1900.html. Diakses 20 November 2018.

[4] National Instruments.(2013). NI myRio user guide and specifications.austin Texas : National Instrument Company.

[5] Christ. (2013). Motor Servo. [Online]. Available in: http://christianto.tjahyadi.com/belajarmikrokontroler/motor-servo.html. accessed 22 November 2018. 